Fiduciary Law and Equity: Enforcing Loyalty

At least in the core area of private trust law, American courts have enforced the fiduciary duty of loyalty strictly. Loyalty is understood as a broad standard of honor, requiring single-minded pursuit of the interests of beneficiaries and avoidance of pressures toward personal enrichment. The general standard is backed by a strict prohibition of self-dealing: transactions between the trustee and the trust are forbidden without specific authorization in the governing trust document or prior judicial approval. ${ }^{1}$ A trustee who breaks this rule is liable for full disgorgement of gains, without further inquiry into the circumstances or reasonableness of the transaction.

This approach to loyalty reflects the traditional methods of equity courts, where trust law first developed. Rather than formulate rules for application by juries, early equity courts examined parties and witnesses in detail, then resolved disputes by applying broad standards of "conscience" to the particular facts that emerged. ${ }^{2}$

To enforce their decisions, they fashioned "in personam" remedies, ordering the defendant to take whatever action seemed appropriate to the case. In some cases, they applied standards of conscience indirectly, as a limit on specific enforcement of established rules of law if

\footnotetext{
${ }^{1}$ See generally IIA Scott on Trusts $\S \S 170.1-170.25$ (Austin Wakeman Scott \& William Franklin Fratcher eds., $4^{\text {th }}$ ed. 1987) (detailing the rule and its many specific variants). Corporate fiduciaries are subject to more lenient rules that allow the fiduciary to prove that the transaction was fair. See, e.g., 1 ALI, Principles of Corporate Governance: Analysis and Recommendations $\S 502 \mathrm{~b}$.

${ }^{2}$ J.H. Baker, An Introduction to English Legal History 103, 105-07 (London: Butterworth's, $4^{\text {th }}$ ed. 2002. For discussion of procedures in Chancery, see John H. Langbein, Renee Lettow Lerner, \& Bruce P. Smith, History of the Common Law: The Development of Anglo-American Legal Institutions 279-80, 289-92 (New York: Aspen Publishers 2009).
} 
enforcement seemed unjust in the circumstances. In other situations, including policing the loyalty of trustees, they applied them directly, as a means of regulating conduct.

I will suggest that the combination of formal and remedial techniques that equity courts applied to the problem of loyalty was geared to deterrence rather than leniency, and these techniques have continued in forced in modern courts. One consequence is that when loyalty and prudence conflict, primacy for loyalty is built into the structure of fiduciary law. Of course the standards can be softened, and the role of loyalty reduced. A change of this type, however, would not be simply a minor adjustment in the law governing trustees but a fundamental structural change.

Below, I briefly track the influence of equity on the development of law pertaining to trustees and other fiduciaries. I then review the structural composition of modern trust law and comment on proposals that for change that would alter the current structure. I suggest that the fiduciary duty of loyalty follows exhibits a structure that is geared toward maximum deterrence, and that this structure is not amenable to corrections designed to provide leniency in cases of good faith breach. Consequently, leniency cannot be accommodated without structural change.

\section{A. Equitable Origins}

Fiduciary law developed in equity in conjunction with the medieval English practice of conveying land to uses. ${ }^{3}$ The English Chancellors enforced uses as a matter of conscience at a time when common law courts recognized only formal legal title to land. After the Statute of Uses abolished most uses, the Chancellors continued to enforce special forms of uses they

\footnotetext{
${ }^{3}$ J.H. Baker lays out the early history succinctly. Baker, supra note X, pp. 248-57. See
} 
deemed not to be affected by the statute, in particular those in which the titleholder undertook active duties to the beneficiary of the use. The standards of conduct the Chancellors developed to enforce the obligations of titleholders, and the remedial devices they employed, continue to be central to fiduciary law.

Equity is no longer a distinct component of the legal system. Nor did it leave behind a clearly defined body of law; equity is definable only as what the Chancellors once did. $^{4}$

Arguably, however, equity performed several identifiable roles in system that are still traceable in modern law. One of these is correction of the errors that follow from rule-governed decision-making. ${ }^{5} \quad$ Another is strong deterrence of certain types of wrongs through a particular combination of formal and remedial techniques.

\section{Corrective Equity and the Problem of Rules}

Much of the common law consists of enabling rules for private transactions, defining the conditions on which a contract or similar arrangement will be enforced by courts. ${ }^{6}$ To serve this

Langbein, Lerner, \& Smith, supra note X, pp. 299-305.

${ }^{4}$ Maitland defined equity as "that body of laws administered by our English courts of justice which, were it not for the operation of the Judicature Acts, would be administered by courts that would be known as Courts of Equity." F.W. Maitland, Equity and also the Forms of Action at Common Law 1 (Cambridge: Cambridge U. Press, J.H. Chaytor \& J. Whittaker, eds., 1929).

${ }^{5}$ This is equity in the Aristotelian sense. See Aristotle, Nicomachean Ethics I11138b25 (Hackett Pub., Terence Irwin, ed. \& trans., 1985) ("And this is the nature of what is decent - rectification of law in so far as the universality of law makes it deficient.").

${ }^{6}$ The most comprehensive source on the benefits of rules and the problems they pose is Frederick Schauer, Playing By the Rules: A Philosophical Examination of Rule-Based Decision-Making in Law and Life (Oxford: Clarendon Press 1991). The points made in this subsection are discussed at length in Larry Alexander and Emily Sherwin, The Rule of Rules: Morality, Rules, and the Dilemmas of Law (Durham: Duke University Press 2001) 
purpose effectively, a rule be general enough to capture a range of transactions without spelling out all possible features these transactions may display. The rule also must be determinate enough to allow parties to predict legal outcomes in advance. ${ }^{7}$ Predictable legal outcomes for a range of cases allow parties to coordinate their actions on the assumption that each will normally behave as the rule requires. ${ }^{8}$ Thus at least before the advent of Legal Realism, rules of common law, tended to be fairly determinate in form.

The dilemma that leads to corrective equity is that general, determinate rules are almost always defective in comparison to the set of ideal outcomes in cases governed by the rules. Because the rulemaker cannot anticipate all particular cases that might fall within the terms of a general, determinate rule, some of the results the rule prescribes will be inconsistent with the rule's objectives or simply wrong, all things considered. It does not follow, however, that the rule should be revised, because human reasoning, by individual parties or by judges, is also non-ideal. Not only will human reasoners make mistakes, but they are likely to place more weight on immediate and salient features of particular cases than on background probabilities such as the effect of a rule violation on the overall coordination value of the rule. ${ }^{9}$

\footnotetext{
${ }^{7}$ See Schauer, Playing By the Rules, 53-68. The arguments made here assume that rules have a core of determinate meaning, even if their meaning is uncertain in some contexts. See generally Kent Greenawalt, Law and Objectivity (New York: Oxford University Press 1992), 34-89; H.L.A. Hart, The Concept of Law (Oxford: Clarendon Press 1961), 122-38; Schauer, supra note 3, at 53-68; Jules L. Coleman and Brian Leiter, Determinacy, Objectivity, and Authority, 142 U. Pa. L. Rev. 549 (1993); Lawrence B. Solum, On the Indeterminacy Crisis: Critiquing Critical Dogma, 54 U. Chi. L. Rev. 462 (1987).

${ }^{8}$ On the coordination effects of rules, see, e.g., Gerald J. Postema, Coordination and Convention at the Foundations of Law, 11 J. Legal Stud.(1982) 165, 172-86.
}

${ }^{9}$ For overviews of the problem of cognitive biases and studies documenting the availability 
Consequently, rule followers will tend systematically to undervalue reasons to follow or enforce the rule when the time comes to act, and will follow it, or enforce it, less often than they ideally should. Each rule violation, in turn, will dilute the coordination value of the rule by undermining the assumption that most people comply.

Given these features of rules and rule-appliers, a rule is justified as long as the results of regular compliance with the rule, including the coordination benefits a reliable rule provides, are likely to be superior, on average, to the rules of particularized judgment in each case. From the general, forward-looking point of view of the rulemaker, when a rule is justified in this sense, itis best that all actors follow the rule, and that judges enforce the rules in all cases, than that actors and judges reconsider their reasons for and against following the rule at the point of action. Yet, from the point of view of parties and judges situated in particular cases, following the rule or enforcing the rule may appear wrong or unjust, all things considered. In some cases, this particularized judgment may be correct, because general rules do in fact generate a certain number of erroneous outcomes. More often, it will be incorrect; but understanding this in the abstract does not alleviate the pressure to depart from the rule in particular cases when appears to requires the wrong result.

Equity courts, whether consciously or not, developed ways of correcting unwanted outcomes of general, determinate rules without completely undermining the benefits associated heuristic and similar patterns of human reasoning, see Daniel Kahneman, Paul Slovic, \& Amos Tversky, eds., Judgment Under Uncertainty: Heuristics and Biases 163)(Cambridge: Cambridge University Press 1982); Daniel Kahneman, Paul Slovic, \& Amos Tversky, eds, Heuristics \& Biases: The Psychology of Intuitive Judgment (Cambridge: Cambridge University Press 2002). See also Jeffrey J. Rachlinski, Bottom-Up and Top-Down Decisionmaking, 73 U. Chi. L. Rev. 933, 942-43 (2006)(discussing the effects of affect and availability biases in judicial decisionmaking). 
with rules. Most often, this occurred through the mechanism of equitable defenses. ${ }^{10}$ Equitable defenses are defenses that apply only to equity remedies such as injunctions. Substantively, equitable defenses typically are based on fact-specific conclusions that one party has engaged in conduct that is permissible within the terms of governing rule but misleading or unfair in context, or that the rule, as applied to the case at hand, imposes a hardship on one party that is grossly disproportionate to the that benefits equitable relief with bring to the other. An equity court might, for example, deny specific performance if it detected a form of deception not recognized as a defense in courts or law or if the defendant made an excusable but mistake in assessing the value of a bargain. ${ }^{11}$ Remedially, the outcome is to deny the equity remedy but leave open the possibility of a legal damage remedy.

Equitable correction of this kind serves two functions in a legal system. One is to deny opportunists the advantages they might otherwise obtain by exploiting the interstices of determinate legal rules. ${ }^{12}$ Another is to allow a degree of leniency for parties who will suffer

${ }^{10}$ See Restatement (Second) of Contracts $§ 364$ (1979)(describing special defenses to the remedy of specific performance.) Edward Yorio discussed equitable defenses at length in his 1989 book on specific performance. Yorio, Contract Enforcement: Specific Performance and Injunctions 73-126 (1989).

${ }^{11}$ See, e.g., Panco v. Rogers, 87 A.2d 770 (N.J. Ch. Div. 1952).

${ }^{12}$ Henry Smith suggests that combatting opportunism is the principle function of equity in modern law. See Henry E. Smith, Why Fiduciary Law Is Equitable, in Philosophical Foundations of Fiduciary Law 261 (Andrew S. Gold \& Paul B. Miller, eds., Oxford U. Press 2014); Yuval Feldman \& Henry E. Smith, Behavioral Equity, 170 J. of Institutional and Theoretical Economics 137 (2014); Henry E. Smith, Equity as Second-Order Law: The Problem of Opportunism, available at http://papers.ssrn.com/sol3/papers.cfm?abstract $\mathrm{id}=2617413$ (January 15, 2015); Henry E. Smith, Equitable Defenses as Meta-Law, forthcoming in Defences in Equity, eds. Paul S. Davies, Simon Douglas, and James Goudkamp (London: Hart Publishing).

For a fascinating discussion of opportunism within legal loopholes, see Leo Katz, Ill-Gotten Gains: Evasion, Blackmail, Fraud, and Kindred Puzzles of the Law (Chicago: University of Chicago Press, 1996). 
significantly from technical applications of legal rules, and perhaps be forced to accept unwarranted settlement demands. By giving judges these options, equitable correction also eases the pressure judges inevitably face when they are called on to apply a general, determinate rule to a particular case in which they believe, rightly or wrongly, that an otherwise good rule has misfired.

Equitable correction inevitably comes at some cost to the reliability and coordination value of rules. To the extent that the process of equitable correction is visible to those who act under rules, observed instances of correction - exceptions in hard cases - will make the rule less reliable as a standard of conduct and a framework for transactions. ${ }^{13} \quad$ At least historically, however, equitable correction of rules operated at a fairly low level of visibility. Equity courts purported to operate as a subordinate components of the system, following rather than challenging the rules of common law. The equitable defenses they recognized came into play only at the remedial stage, and so were less likely than common law rules to enter into the parties' predictions at the time of a transaction. Further, because they affected only equitable relief, they also appeared limited in scope. Given the traditional maxim holding that equitable remedies are available only when legal relief is inadequate, this appearance may have been misleading, but it is likely nevertheless to have provided a type of protective cover for equitable correction of law. The result was a rough compromise between the long-term values associated with dependable rules of conduct and the seeming irrationality of applying a rule to a particular case in which the rule appears to prescribe

\footnotetext{
${ }^{13}$ If exceptions were perfectly calibrated to the need for correction, this might represent an even trade between rule values and improved outcomes in particular cases. Yet, on the assumption that the rule in question is a good rule, such that, taking coordination value into account, regular enforcement of the rule will produce better outcomes on average than particularized judgment, the trade results in a net loss.
} 
the wrong result.

American Legal Realism eliminated much of the cover provided by the traditional methods of equity. Most Realists were skeptical about the integrity of determinate rules and their capacity to guide decision-making. ${ }^{14}$ Accordingly, they brought equity to the forefront of law, explicitly integrating notions such as fairness, bad faith, and unconscionability into rules of conduct. $^{15}$ As a result, equitable correction is now far more visible, and consequently more likley to erode the benefits of general, determinate rules. But that is another story. ${ }^{16}$

\section{Equitable Standards of Conduct}

There is a sense in which early fiduciary law was itself a form of equitable correction of rules. Medieval common law recognized only titles established by certain recognized forms of transfer, subject to fixed rules of devolution and carrying certain obligations to within the

\footnotetext{
${ }^{14}$ See, e.g., Jerome Frank, Law and the Modern Mind (New York: Brentano's 1930), 111 (“The peculiar traits, dispositions, biases and habits of the particular judge will, then, often determine what he decides to be the law); Karl N. Llewellyn, The Bramble Bush: Some Lectures on the Law and Its Study 2-4 (New York: Oceana, 1930), 64-69 ("every single precedent, according to what may be the attitude of future judges, is ambiguous, is wide or narrow at will") (emphasis omitted); Karl N. Llewellyn, A Realistic Jurisprudence - The Next Step, 30 Colum. L. Rev. 431(1930), 447-48 (discussing the difference between "paper rules" and the "real rules" that govern decisions). See generally Brian Leiter, American Legal Realism, in The Blackwell Companion to Philosophy of Law and Legal Theory (Oxford: Blackwell, Dennis Patterson ed., 2d ed. 2010) 249, 253-54 (discussing Realist endorsement of "rational" indeterminacy).

${ }^{15}$ Examples can be found in the Uniform Commercial Code and in Realist inspired Restatements. See, e.g., U.C.C. $\$ 1-304$ (good faith in performance and enforcement), (2-302)(unconscionability); Restatement (Second) of Contracts $\S 1153$ (unilateral mistake), 205 (good faith and fair dealing) (American Law Institute, 1979). Stephen Subrin describes a similar incorporation of equity methods into civil procedure. See Stephen N. Subrin, How Equity Conquered Common Law: The Federal Rules of Civil Procedure in Historical Perspective, 135 U. Pa. L. Rev. 909 , 962-74 (1987).

${ }^{16}$ See Emily Sherwin, Law and the Modern Mind (forthcoming).
} 
structure of feudal landholding. Landowners and their lawyers responded with the device of uses, in which one party undertook to hold formal title on behalf of a series of others, allowing the landowner to avoid feudal duties and choose a pattern of succession. Equity courts intervened to enforce the use if the titleholder chose to disregard the undertaking and appropriate the benefits of the land, and thus correct opportunistic outcomes of the rules governing title.

After the Statute of Uses, equity courts continued to enforce use-like arrangements established through creative conveyancing techniques designed to avoid the effects of the statute. Gradually, these arrangements changed character, shifting from methods of avoiding feudal obligations to devices for wealth management. In response, the courts imposed a number of duties on titleholders, now called trustees. ${ }^{17}$

In this context, the role of conscience shifted from correction of rules to establishment of a regulatory regime. The principal duty the courts imposed on trustees was the duty of loyalty, which reflected the obligations imposed by good conscience on a person entrusted to hold property for the benefit of another. In this context, the broad standards, fact-intensive decisionmaking, and strong remedies associated with equity proved very effective in developing and enforcing the trustee's duty. The primary formal technique of the courts was to establish a vague but comprehensive standard of behavior for fiduciaries, stated in the broadest possible terms. The classic American case of Meinhard v. Salmon, cited in more than 1700 subsequent decisions, illustrates the breadth of the duty: "Not honesty alone, but the punctilio of an honor the most sensitive, is . . the standard of behavior."18

\footnotetext{
${ }^{17}$ See generally, Langbein, Lerner, and Smith, supra note $\mathrm{X}$ at $309-10$.

${ }^{18}$ Meinhard v. Salmon, 164 N.E. 545, 546 (N.Y. 1928). This fairly ordinary case has been cited in at least 1176 decisions and 1642 secondary sources (Westlaw October 7, 2017).
} 
As the law developed, the primary standard of loyalty was coupled with a general and highly determinate rule strictly forbidding self-dealing by trustees, backed by a further rule foreclosing judicial inquiry into the trustee's good or bad faith or background circumstances that might be offered in justification of the trustee's action. ${ }^{19}$ Thus, without authorization in the trust or advance permission from a court, the trustee could not engage in any form of transaction with the trust. The general standard of loyalty, and the accompanying rule against self-dealing, were backed by the most powerful remedies available to equity courts: the trustee was required to account for and disgorge any profits from the transaction, as well as products and proceeds of initial profits. ${ }^{20}$

\section{B. Modern Trust Law and Proposals for Change}

At least three formal structures and remedial structures are observable in modern trust law, two of which bear the influence of equity. The initial creation of fiduciary relationships is a matter of contract law, governed by the rules of common law as they have evolved over time. Rules of contract formation are relatively determinate in form. Their primary functions are to support coordination of private choices and enable parties to enter reliable transactions.

Although certain behavior, such as fraud, will render an attempted contract invalid, the primary objective of the rules is not to deter unwanted behavior. In fact, the relative clarity of the rules may invite opportunistic parties to engage in conduct that violates the objectives of the rule but is not captured by its terms.

\footnotetext{
${ }^{19}$ See IIA Scott on Trusts $\S \S 170.1-170.25$, supra note X.

${ }^{20}$ For an early statement of the breadth of the remedy, see James Barr Ames, Following Misappropriated Property Into Its Product, 19 Harv. L. Rev 511 (1905).
} 
Ordinary rules of contract law continue to be are subject to a certain amount of equitable correction of the kind described earlier. Courts may intervene both to capture the fruits of opportunism and to provide relief against unwarranted hardship resulting from strict enforcement of the rules. Under the influence of Legal Realism, equitable correction of rules probably is more visible than it once was, and rules are correspondingly less reliable. The basic structure, however, is one of enabling rules tempered by relatively modest policing by courts.

Once a fiduciary relationship is in place, the principal duties imposed on trustees are the duty of care and the duty of loyalty. In the area of care, and particularly of careful investment, the standards of "conscience" and fact-specific decisional techniques traditionally associated with equity failed to produce workable standards of behavior for trustees. Courts first limited the powers of trustees, then devised lists of approved investments, then developed the "prudent man" standard, which encouraged trustees to mimic the actions of cautious investors dealing with property of their own. ${ }^{21}$ Legislatures eventually responded by enacting the Uniform Prudent Investor Act, which provides trustees with a body of economically tested principles for investment of trust assets. ${ }^{22}$

Thus in modern law, the trustee's duty of care is governed by a set of primarily legislative guidelines. These guidelines embody the economic knowledge of the experts who formulate them and communicate this expertise to less skilled fiduciaries. They also provide a safe harbor against liability. Their purpose, therefore, is not to deter but to educate. Nor is the form of the

\footnotetext{
${ }^{21}$ See generally Robert H. Sitkoff \& Jesse Dukeminier, Wills, Estates, and Trust (N.Y.: Wolters Kluwer, 10 ${ }^{\text {th }}$ ed. 2017), 626-32; Max M. Schanzenbach \& Robert H. Sitkoff, The Prudent Investor Rule and Market Risk: An Empirical Study, 14 J. Empirical L. Stud. 129, 133-40 (2017).

${ }^{22}$ Uniform Prudent Investor Act (cite)
} 
guidelines likely to attract opportunism or to cause hardship in ways that call for judicial intervention. Thus, the dut $y$ of case is no longer equitable in any meaningful sense.

In contrast, the regulatory regime courts developed to define and enforce the trustee's duty of loyalty has been much more durable. Loyalty continues to be broadly defined by a standard of honor, reinforced by a strict and determinate rule forbidding transactions between the trustee and the trust, and enforced by powerful disgorgement remedies. In the event the trustee breaks the rule against self-dealing, the court will hold the trustee liable without consideration of surrounding facts, the trustee's good faith, or the outcome of the transaction.

A well-known illustration of this approach to loyalty is Will of Gleeson. ${ }^{23}$ Mrs. Gleeson appointed Colbrook, the tenant of her 160-acre farm, as executor of her will and trustee of a testamentary trust for her three children (two daughters and a son who was described in the opinion as incompetent). Reading between the lines, Colbrook appears to have accepted these responsibilities out of a sense of duty to Mrs. Gleeson and her family.

Mrs. Gleeson died on February 14, 1952. On March $1^{\text {st }}$, while estate proceedings were pending, Colbrook renewed his own farm lease for an additional year, as permitted by the terms of the lease. He and a partner continued to farm the land until March 1953, when he leased it to another party. The trust beneficiaries later filed an objection to Colbrook's accounts as trustee, seeking disgorgement of Colbrook's share of the farm profits for 1953. Colbrook defended on a number of grounds tending to show that his dealings with the trust had been honorable and perhaps necessary to protect the interests of beneficiaries. The 1952 farming season had begun just 14 days after Mrs. Gleeson's death and replacement farm tenants were not readily available.

${ }^{23} 124$ N.E.2d 624 (IIl. App. 1955). 
In renewing the lease, Colbrook acted openly and discussed the transaction with the two competent trust beneficiaries. He voluntarily raised his own rent for 1952 from $\$ 6$ to $\$ 10$ per square acre. Nevertheless, the appellate court required Colbrook to disgorge all of his farming profits for the period of the renewed lease, citing the rule against self-dealing and the accompanying rule of no-further-inquiry into the circumstances or outcome of the transaction. "[T]he good faith and honesty of the petitioner or the fact that the trust sustained no loss on account of his dealings therewith ... can avail petitioner nothing so far as a justification of the course he chose to take. ..."24

This is a harsh outcome: Colebrook was an amateur trustee, who assumed his fiduciary position as a favor, probably had never heard of the rule against self-dealing, and probably was unaware of procedures for prior judicial approval. His primary strategy appeared to be to maximize the trust income in the year following Mrs. Gleeson's death. And in fact, continuing the lease appears to have been the best plan for managing the farm.

The decision, however, is understandable if the overriding goal of law in this area is deterrence. There are several reasons to think that this is the case. Most obviously, fiduciaries, and particularly trustees, are perfectly situated to act in opportunistic ways. They have decisionmaking power over assets intended for the benefit of others and the intended beneficiaries are often unsophisticated, uninterested in management, or unascertained..$^{25}$ Another problem is

\footnotetext{
${ }^{24}$ Id. at 627 . The court pointed out that there was no evidence that Colbrook had tried to obtain a new tenant in 1952, and that if he wanted to continue the lease, he could have declined the act as executor and trustee. Will of Gleeson is now more than 60 years old, but the rule it states is still regularly cited and applied. See Restatement (Third) of Trusts, supra note 26, § 78, cmt b (2007).

${ }^{25}$ For a succinct statement of this point, see Robert H. Sitkoff, An Economic Theory of Fiduciary Law, Philosophical Foundation of Fiduciary Law, (Andrew S. Gold and Paul B. Miller, eds, New York: Oxford U. Press 2014). A similar argument appears in Melanie B. Leslie, In Defense of
} 
that even trustees who intend to act in good faith may be influenced in subtle ways to favor their own interests in transactions with the trust. ${ }^{26}$

Apart from the obvious need for deterrence in this context, the deterrent goal of the law governing trustee loyalty is confirmed by the formal and remedial structure equity courts developed for dealing with questions of loyalty, which naturally lends itself to strong deterrence. A broad standard of conduct such as "honor" not only sets a high bar; the uncertainty it creates also gives the fiduciary reasons to avoid any conduct that might later be deemed to fall within the terms. In this respect, the effect of an indeterminate standard on fiduciary conduct is opposite to the effect of a determinate rule of conduct, which invites the fiduciary to engage in transactions that might involve a conflict of interest but do not fall within the precise terms of the rule.

In the traditional doctrinal formulation the court affirmed in Will of Gleason, the standard of honor is coupled with a relatively determinate rule forbidding trustees from engaging in transactions with the trust. In this setting, however, a determinate rule does not invite opportunism because it operates within the broader framework of the standard of loyalty. Finally, both the standard of loyalty and rule accompanying rule against self-dealing are enforced through equitable remedies that require full disgorgement of profits. $^{27}$

This regulatory pattern naturally lends itself to deterrence. It is also difficult to explain in the No Further Inquiry Rule: A Response to Professor John Langbein, 47 Wm. \& Mary L. Rev. 541 (2005).

${ }^{26}$ See Restatement (Third) of Trusts $\S 78 \mathrm{cmt} \mathrm{b}$ (2007) (citing the following remark in Daniel Gilbert, "I'm OK, You're Biased," The New York Times (Apr. 16, 2006), sec. 4, p. 12: “[b]ecause the brain cannot see itself fooling itself, the only reliable method for avoiding bias is to avoid the situations that produce it").

${ }^{27}$ See Ames, supra note X. 
other terms, such as coordination or guidance. The duty of loyalty, as currently framed and enforced, may sometimes thwart a transaction that could maximize the value of trust assets, and it may lead to substantial penalties for fiduciaries who have acted in good faith. ${ }^{28}$ At least for trustees who act knowingly, however, it is highly effective as a means of preventing self-interested transactions by unmonitored fiduciaries.

Suggestions have been for modification of the duty of loyalty to allow trustees to justify self-interested transactions after the fact. In particular, John Langbein has criticized the strict prohibition on self-dealing and related no-inquiry rule, which he attributes to procedural and fact-finding deficiencies of equity courts that are longer present under modern rules of procedure modern courts. ${ }^{29}$ In Langbein's view, these features of the duty of loyalty over-deter transactions in which the trustee has an interest, barring creative solutions to asset management problems that may in fact advance the interests of trust beneficiaries. In Langbein's terms, trustees are penalized for failing to act in the sole interest of their beneficiaries when in fact their actions were in the best interests of the beneficiaries. Langbein proposes instead that trustees should not be required to disgorge profits if they are able to show that their actions were justified. In cases of self-dealing, breach of loyalty should be presumed unless the trustee produces good evidence that the transaction in question served the interests of beneficiaries. ${ }^{30}$

\footnotetext{
${ }^{28}$ This suggestion assumes that trial court judges will in fact apply the standards mandated by appellate courts. In Will of Gleeson, this appears not to have been the case.

${ }^{29}$ John H. Langbein, Questioning the Trust Law Duty of Loyalty: Sole Interest or Best Interest?, 114 Yale L. J. 929 (2005). See also Gregory S. Alexander, A Cognitive Theory of Fiduciary Relationships, 85 Cornell L. Rev. 767 (2000) (suggesting that courts tend to judge fiduciaries according to relational "schemas" rather than hard facts).

${ }^{30}$ For criticism of Langbein's position, see Leslie, supra note X.

Langbein suggests that a standard of proof by clear and convincing evidence provides a
} 
The effect of this proposal is to apply the technique of equitable correction to the strict rule against self-dealing that traditionally supplements the standard of trustee loyalty. In this setting, equitable correction takes the form of leniency. The point is not to deter opportunism that might occur in response to the underinclusiveness of a rule, but to soften the effects of a rule deemed too strict.

Langbein's proposal exemplifies the Legal Realist assumption that more equity, at least in the corrective sense of equity, is always better. In transactional settings, the problem with this assumption is that equitable correction of rules will at some point undermine the coordination value of the rules. In the area of fiduciary loyalty, the effect is more immediate. Because the rule against self-dealing is imbedded within a maximally deterrent standard of loyalty and backed by strong remedies, the effect of equitable correction is not just to cast doubt on the reliability of the rule but to alter the structural and purpose of the current body of law. The effect of the prevailing combination of a broad standard of conduct and a strict supporting rule is to prevent trustees from exercising judgment about the prospect of self-dealing. In effect, Langbein's

appropriate limitation on leniency toward trustees who self-deal. Langbein, supra note $\mathrm{X}$, at 987. This standard has a number of difficulties, apart from its impact on deterrence. To the extent that the goal of proof is to indicate truth, a preponderance standard will be more accurate on average than a standard of clear and convincing evidence. The clear-and-convincing standard is also vague: the meaning of a preponderance of evidence is reasonably clear, and proof beyond a reasonable doubt is understandable, but clear and convincing evidence is just somewhere in between. Consequently, disputes are less likely to settle than they might be under a preponderance standard. See George L. Priest \& Benjamin Klein, The Selection of Disputes for Litigation, 13 J. Legal Stud. 1, 9-15 (1984)(demonstrating that parties are more likely to pursue litigation when outcomes are uncertain). Most important for the present purpose, the clear-and-convincing standard is a litigation standard, which comes into play when a dispute arrives in court and may not be salient at the time of behavior. It follows that a clear-and-convincing proof requirement is not likely to limit the impact that introduction of equitable correction through leniency would have on the current structure of legal regulation of trustee loyalty. 
proposal for equitable correction of the rule would converts the standard of loyalty and the rule against self-dealing into a set of guidelines for trustee decisionmaking, leaving it to the trustee to determine whether a proposed transaction is justifiable, all things considered. ${ }^{31}$

The resulting regime of guidance would lace a less onerous burden on amateur trustees. It also might permit some useful transactions that currently are barred. It would, however, fundamentally change the structure of judicial regulation of trustee loyalty.

\section{Conclusion}

Several formal and remedial components of modern fiduciary law are traceable to the equity. In some settings, such as the duty of care, equity no longer serves a useful purpose and has been abandoned. In others, such as the contractual arrangements on leading to fiduciary undertakings, equity continues to play a role in decisionmaking but that role is not unique to fiduciary law. Elsewhere, especially in the context of the duty of loyalty imposed on trustees, structures inherited from equity still perform vital functions in field. These structures can perhaps be altered, but not without affecting the functions associated with them.

\footnotetext{
${ }^{31}$ In other areas of fiduciary law, in which there are additional market-based limits on fiduciary conduct, a more lenient standard of conduct, or a standard coupled with the possibility of equitable correction in particular cases, may be warranted depending on the assumptions one makes about other constraints on the behavior of corporate managers. See, e.,g., Robert H. Sitkoff, Trust Law, Corporate Law, and Capital Market Efficiency, 28 J. Corp. L 565, 572-74 (2003).
} 